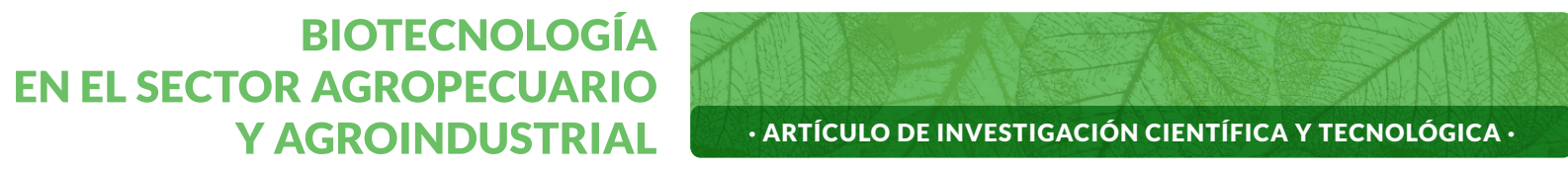

Vol. 20 No 1 · Enero-Junio 2022 · ISSN-1692-3561 · ISSN-e 1909-9959 · DOI: https://doi.org/10.18684/bsaa.v.n.2022.1827

\title{
The influence of milk-clotting enzymes on the lipid composition and organoleptic properties of semi-matured cheeses*
}

\section{Influencia de las enzimas coagulantes de la leche sobre la composición lipídica y propiedades organolépticas de quesos semi-madurados}

\author{
USGAME-FAGUA, KAREN-GINETH ${ }^{1 *}$; GARCÍA-TORRES, ANGÉLICA-MARÍA²; \\ ROJAS-MORALES, CARLOS-IVÁN³; MEDINA-VARGAS, OSCAR-JULIO ${ }^{4}$
}

Historial del artículo

Recibido para evaluación: 12 enero 2021.

Aprobado para publicación: 27 julio 2021.

* $\quad$ Proyecto de origen: "Implementación de membranas cerámicas en el proceso de elaboración del queso Paipa, su efecto en la calidad microbiológica y el contenido de ácido linoleico conjugado-SGI 2140" e "Innovación tecnológica en queso Paipa y su efecto en el contenido de ácido linoleico conjugado como potencial alimento functional-SGI 2396”. Financiación: Dirección de Investigaciones de la Universidad Pedagógica y Tecnológica de Colombia DIN-UPTC. Culminación: en ejecución.

1 Universidad Pedagógica y Tecnológica de Colombia (UPTC), Facultad de Ciencias, Maestría en Química, Grupo de Investigación en Química y Tecnología de Alimentos (GIQTA). Químico. Tunja, Colombia. https://orcid.org/0000-0001-8544-2542

2 Universidad Pedagógica y Tecnológica de Colombia (UPTC), Facultad de Ciencias, Escuela de Ciencias Químicas, Grupo de Investigación en Química y Tecnología de Alimentos (GIQTA). Doctora en Química. Tunja, Colombia. https://orcid.org/00000003-4014-7931

3 Universidad Pedagógica y Tecnológica de Colombia (UPTC), Facultad de Ciencias, Escuela de Ciencias Biológicas, Grupo de Investigación en Química y Tecnología de Alimentos (GIQTA). Magister en Ciencias Biológicas. Tunja, Colombia. https://orcid. org/0000-0002-3330-7469

4 Universidad Pedagógica y Tecnológica de Colombia (UPTC), Facultad de Ciencias, Escuela de Ciencias Químicas, Grupo de Investigación en Química y Tecnología de Alimentos (GIQTA). Doctor en Tecnología de Alimentos. Tunja, Colombia. https:// orcid.org/0000-0001-6609-356X 


\section{ABSTRACT}

The milk-clotting enzymes used in the production of semi-matured and matured cheeses, can influence the metabolic processes that occur during maturation. This study evaluated the impact of chymosin enzyme E.C. 3.4.23.4 (recombinant and microbial origin) on the lipid composition and organoleptic properties of Paipa Cheese, a semi-mature artisan Colombian product. The lactic acid bacteria content in milk and Paipa cheese, the coagulant and lipolytic activity of chymosin, the lipid composition as well as the lipid profile of the product, total free fatty acids, and sensory analysis were evaluated. The results indicated a greater lipolysis in cheeses made with chymosin microbial origin which were associated with a greater lipolytic activity and a greater perception of acidic, rancid, and soapy flavors. Nevertheless, panelists preferred cheese prepared using recombinant chymosin, with lower lipolysis and lipolytic activity. Regardless of the type of protein precipitant that can be used in the elaboration of semi-matured and matured cheeses, Paipa cheese had a high content of saturated fatty acids and omega 3, 6, and 9; which accounted for the organoleptic and nutritional characteristics, which could favorably impact its commercial activity.

\section{RESUMEN}

Las enzimas coagulantes de la leche utilizadas en la producción de quesos semi-madurados y madurados pueden influir en los procesos metabólicos que se producen durante la maduración. Este estudio evaluó el impacto de la quimosina E.C. 3.4.23.4 (de origen recombinante y microbiano) en la composición lipídica y las propiedades organolépticas del queso Paipa, un producto colombiano artesanal semi-madurado. Se evaluó el contenido de bacterias ácido lácticas en la leche y el queso Paipa, la actividad coagulante y lipolítica de la quimosina, la composición lipídica, así como el perfil lipídico del producto, ácidos grasos libres totales y análisis sensorial. Los resultados indicaron una mayor lipólisis en los quesos elaborados con quimosina de origen microbiano, los cuales se asociaron con una mayor actividad lipolítica y una mayor percepción de sabores ácidos, rancios y jabonosos. No obstante, los panelistas prefirieron el queso preparado con quimosina recombinante, con menor lipólisis y actividad lipolítica. Independientemente del tipo de precipitante proteico que se pueda utilizar en la elaboración de quesos semi-madurados y madurados, el queso Paipa presenta un alto contenido de ácidos grasos saturados y omega 3, 6 y 9; lo que da cuenta de las características organolépticas y nutricionales, que podrían impactar favorablemente su actividad comercial.

Correspondence: karen.usgame@uptc.edu.co

Cómo citar este artículo: USGAME-FAGUA, KAREN-GINETH; GARCÍA-TORRES, ANGÉLICA-MARÍA; ROJAS-MORALES, CARLOS-IVÁN; MEDINA-VARGAS, OSCAR-JULIO. The influence of milk-clotting enzymes on the lipid composition and organoleptic properties of semi-matured cheeses. Revista Biotecnología en el Sector Agropecuario y Agroindustrial, v. 20, n. 1, 2022, p. 97-112. Doi: https://doi. org/10.18684/bsaa.v.n.2022.1827

\section{KEYWORDS:}

Paipa cheese; Chymosin, Maturation; Lipid profile; Free fatty acids; Lipolysis; Lipolytic activity; Lactic acid bacteria.

\section{PALABRAS CLAVE:}

Queso Paipa; Quimosina; Maduración; Perfil lipídico; Ácidos grasos libres; Lipólisis; Actividad lipolítica; Bacterias ácido-lácticas. 


\section{INTRODUCTION}

Paipa cheese is a semi-mature artisan cheese which is typical of the Colombian Andean region. Some of its original organoleptic characteristics are a featured mild bitter flavor, a strong and moderate rancid aroma, and a semi-dry texture. These characteristics come in part from the raw milk obtained from the region's own cattle. These characteristics are only possible because of the natural environment and local production customs of the region with which it is associated. As a result of these characteristics it has been granted protection under the designation of origin (PDO) (Superintendencia de Industria y Comercio de Colombia-SIC, 2011). The manufacturing process includes the transformation and/or separation of casein (due the hydrolysis of the Phe105 Met106 bond of k-casein) which is the main protein in milk. This is accomplished using enzymatic coagulation by adding proteolytic enzymes: chymosin (E.C. 3.4.23.4) known as commonly "milk-clotting enzymes". As a result of this process, a milk curd or gel is obtained which is mainly composed of fat and proteins. This results in a strong tendency for the syneresis phenomenon to occur, exuding a significant part of the milk whey (Romero Del Castillo-Shelly and Mestres-Lagarriga, 2004). The traditional protocol for making Paipa cheese does not specify the type of precipitating agent to be used during its manufacture. Producers choose a clotting agent based on economic factors and the known results of the changes. These changes in the taste and smell of the product demonstrate the need for knowledge which allows the producer to accurately assess the type and degree of changes on the organoleptic properties of this type of cheese.

Milk-clotting enzymes, chymosin, are in constant demand in the dairy industry; for this reason, there is a wide variety of protein precipitants whose origin could affect their specificity and properties, so their use could be limited to the kind of dairy product to be manufactured (Romero Del Castillo-Shelly and Mestres-Lagarriga, 2004). Two of the most commercially enzymes are recombinant chymosin (RC), $100 \%$ pure recombinant chymosin secreted by Aspergillus niger var. awamori, by genetic engineering techniques, and chymosin microbial origin (CMO), an aspartic protease obtained by the controlled fermentation of Rizhomucor Miehei. These precipitants differ in origin as well as in the content of proteolytic and lipolytic enzymes which remain in the cheese-product, favoring different metabolic processes during maturation. In the case of lipid metabolism, the milk-clotting enzymes are related to the release of free fatty acids (FFA) which are the precursors to volatile compounds such as carboxylic acids, alcohols, ketones, thioesters, and other agents responsible for the safety of the product and its organoleptic properties; mainly odor and taste (Bertuzzi et al., 2018). Studies associated to the use of CMO in the production of Camembert, Cheddar, and Edam, have shown that their use favors proteolysis and lipolysis related to bitter flavors in hard, long-maturing cheeses (Reps et al., 2006); these protein precipitants have been widely accepted at the industrial level given their high coagulant activity and low non-specific proteolytic activity. RC have been characterized by their high specificity, low non-specific proteolytic activity, predictable coagulation behavior, and conducive to vegetarian diets just like CMO ((Romero Del Castillo-Shelly and Mestres-Lagarriga, 2004). When comparing Paipa Cheeses from different Colombian companies, differences were found in their composition and appearance (data not shown). This may be directly connected to the absence of studies that identify the impact of the type of protein precipitant on its organoleptic and nutritional characteristics.

As an experimental procedure for the present investigation it was necessary to carry out both preliminary tests on fresh raw milk and on Paipa cheeses. The objective of this work was to evaluate the influence of the kind of chymosin (recombinant and microbial origin) on the lipolytic activity, lipid composition and organoleptic properties for the particular case of a dairy product. These aspects account for the importance of milk-clotting enzymes on the organoleptic and nutritional properties of semi-matured and matured cheeses; while providing the possible impact it may have on its commercial activity. 


\section{METHODS}

\section{Preliminary tests on fresh raw bovine milk}

Both collection of raw milk and maturation of cheeses were carried out in Paipa, municipality of the department of Boyacá (central-eastern Colombia). It is at an elevation of $2.525 \mathrm{~m}$, the climate is mild with an average of 13,7 ${ }^{\circ} \mathrm{C}$ and relative humidity $70-78 \%$. The different assays were developed at the Universidad Pedagógica y Tecnológica de Colombia located in Tunja (capital of Boyacá department), 48 km of Paipa.

Three batches of milk were collected, each with a content of $11 \mathrm{~L}$. Each cheese required 5,5 L of milk from Norman, Holstein, and Jersey breeds of cattle and their respective crosses. The cattle were raised on dairy farms in the municipality of Paipa and its surrounding areas. The selection of livestock relied on farms with a non-specialized dairy production system using animals in adequate body condition. The animals had a diet based on kikuyu and ryegrass, mineralized salt, and did not receive any type of food supplement. Each analysis within the preliminary tests were performed in triplicate and included:

Physicochemical composition. To assess the quality and composition of the milk, $\mathrm{pH}$, protein percentage, percentage of total solids, and fat percentage were determined using a LactoScan SA30 dairy analyzer that meets the requirements established by the AOAC. The percentage of acidity was measured by titration with $\mathrm{NaOH}$, AOAC 947.05 method (1990).

Lactic acid bacteria content. Lactic acid bacteria content was quantified because these microorganisms are the main source of lipolytic enzymes in matured cheeses and influencing both lipid metabolism and the organoleptic properties in the final product. The count of lactic acid bacteria (LAB) required the preparation of serial dilutions in base 10 of milk in sterile peptone water. One milliliter of the diluted sample was inoculated in plates for microbial count ( $3 \mathrm{M}$ Petrifilm) and incubated for $48 \pm 3 \mathrm{~h}$ at temperatures between 28 and $37^{\circ} \mathrm{C}$ as indicated by AOAC PTM 041701 (1990).

Coagulant activity of the milk-clotting enzymes. This process allowed the evaluation of the strength or coagulation capacity of the precipitant. One unit of coagulant activity (UCA) corresponds to the amount of enzyme extract (minimal chymosin concentration $530 \mathrm{mg} / \mathrm{L}$ ) necessary to coagulate $10 \mathrm{~mL}$ of skimmed milk reconstituted in $100 \mathrm{~s}$ at $30^{\circ} \mathrm{C}$. It was calculated using equation 1 (Amira et al., 2018).

Coagulant activity $\left(\frac{\mathrm{UCA}}{\mathrm{mL}}\right)=\frac{10 \times \mathrm{V}}{\mathrm{Tc} \times \mathrm{V}^{\prime}}$

Where: $\mathrm{UCA} / \mathrm{mL}=$ units of coagulant activity per milliliter, $V=$ volume of milk $(\mathrm{mL}), T c=$ coagulation time $(\mathrm{s}), V^{\prime}=$ quantity of enzyme extract $(\mathrm{mL})$.

Lipolytic activity of the milk-clotting enzymes. In order to quantify the lipase activity of the enzymes from the coagulants and define the amount of enzyme that produces an evaluable FFA. One $\mu \mathrm{Eq}$ of $\mathrm{NaOH}$ was added until a pH of 8,5 was reached on a cream substrate after being incubated for $24 \mathrm{~h}$ at $37^{\circ} \mathrm{C}$ (Bevilacqua et al., 2019). It was calculated using equation 2.

Lipolytic activity $\left(\frac{L U}{g}\right)=\frac{(A-B-C) D}{E \times 10^{-6}}$ 
Where: $\mathrm{LU} / \mathrm{g}=$ lipolytic units per gram of coagulant, $A=$ volume of $\mathrm{NaOH}$ used in the neutralization $(\mathrm{mL}), B=$ volume of $\mathrm{NaOH}$ used in the neutralization of the blank $(\mathrm{mL}), \mathrm{C}=$ volume of $\mathrm{NaOH}$ used in the neutralization of the precipitant extract $(\mathrm{mL}), \mathrm{D}=$ concentration of $\mathrm{NaOH}, \mathrm{E}=$ volume of sample $(\mathrm{mL})$.

The selection of RC and CMO coagulants, was chosen according to preferences of the Paipa cheese producers. The current study used the chymosin microbial origin: Microclerici rennet, Caglificio Clerici, Sacco system (Italy): a precipitant of fungal origin obtained by the controlled fermentation of Rizhomucor miehei, whose active component is the aspartic protease of Rizhomucor miehei. The current study also used the recombinant chymosin Albamax rennet, Caglificio Clerici, Sacco system (Italy): a 100 \% pure recombinant chymosin secreted by Aspergillus niger var. awamori, whose active component is particularly Chymosin B.

\section{Preparation and testing of Paipa cheese}

Paipa cheeses were made in laboratory using 5,5 L of milk each, following the manufacturing protocol established in resolution 70802 of the Superintendency of Industry and Commerce of Colombia The resolution states the conditions and stages for the manufacturing of the cheese, protected designation of origin (PDO). The fresh and raw milk must first be filtered using a cloth, heated to between 30 and $35^{\circ} \mathrm{C}$, and curdled for $35 \mathrm{~min}$ from the addition of $1 \%$ of milk-clotting enzyme by volume of milk (SIC, 2011). The curd formed must then be cut and agitated, sat and drained to a malleable wet mass, kneaded and salted using $11 \mathrm{~g}$ of cooking salt, and molded and pressed for $10 \mathrm{~h}$ in round perforated plastic molds with a capacity of $450 \mathrm{~g}$. Only after this process can it be let to mature for 21 days in a cellar at temperatures between 15 and $20^{\circ} \mathrm{C}$ and a controlled relative humidity between 65 and $70 \%$. Three batches of Paipa cheeses were made, each consisting of two cheeses; one cheese made using the recombinant chymosin $(\mathrm{RC})$ and another using the chymosin of microbial origin (CMO). Each analysis that made up the tests on the cheeses were performed in triplicate and included:

Physicochemical composition. $\mathrm{pH}$ was determined using a $\mathrm{pH}$ meter, following the AOAC 981.12 method (1990). Salt percentage was determined using $\mathrm{AgNO}_{3}$, following the $\mathrm{AOAC} 935.43$ method (1990). The percentage of protein and the percentage of dry protein was measured using the Kjeldahl method, following the AOAC 920.123 (1990). The percentages of total solids, humidity and humidity in defatted cheeses were measured using AOAC 926.08 (1990). The percentages of fat and fat in dry material were measured using gravimetric analysis using AOAC 933.05 (1990). Water activity was measured at $20^{\circ} \mathrm{C}$ according to the standard AOAC 978.18 (1990). The acidic percentage was measured according to the method described in AOAC 920.124 (1990). The percentage yield was calculated based on the average theoretical yield obtained in the production of Paipa cheese (Niño De Onshuus, 1998).

Lactic acid bacteria content. Five grams of cheese was macerated in $45 \mathrm{~mL}$ of sterile peptone water and $100 \mu \mathrm{L}$ of tween 80 was added. Serial dilutions in base 10 of the sample were then prepared in sterile peptone water. One milliliter of the diluted sample was inoculated on plates of $3 \mathrm{M}$ microbial counting petrifilm and the plates were incubated for $48 \pm 3 \mathrm{~h}$ at temperatures between 28 and $37^{\circ} \mathrm{C}$ according to AOAC PTM 041701(1990).

\section{Lipid composition}

Lipid Profile. The analysis of the fatty acids extracted from $100 \mathrm{~g}$ samples of cheese was carried out by extracting and quantifying their methyl esters on an AT 6890N gas chromatograph (Agilent Technologies, Palo Alto, California, U.S.A.) with a flame ionization detector (GC-FID) according to the automated Soxhlet extraction method and ISO 12966-1:2014/ISO 12966-2:2017 standards. 37 Component FAME Mix, (AccuStandard, Inc., 125 Market Street, New Haven CT 06513, Cat FAMQ-005) was used as a certified reference standard. The column used in the analysis was a DB-23 (J \& W Scientific, Folsom, CA, USA) [50 \%-cyanopropyl-poly(methylsiloxane), $60 \mathrm{~m} \times 0,25 \mathrm{~mm} \times 0,25 \mu \mathrm{m}]$. The injection used was $2 \mu \mathrm{L}$ in volume and was done in split mode (50:1). 
Total FFA quantification. In order to evaluate the influence of the type of chymosin (E.C. 3.4.23.4) on lipolysis or release of FFA in cheeses, the "copper soaps" spectrophotometric method was used (Câmara et al., 2017).

Sensory analysis. In order to evaluate the organoleptic properties of the elaborated Paipa cheeses, the sensory panel required the training of 16 individuals. The individuals were trained during a non-continuous time of $8 \mathrm{~h}$ with different commercial Paipa cheeses. The attributes evaluated were visual appearance, manual and mouth texture, flavor, and an olfactory and retronasal evaluation. The information was recorded in an evaluation format designed by the authors of this paper. Each panelist rated the perceived intensity of each attribute on a scale from 0 to 5 , with 0 being the total absence of the attribute and 5 being the presence at a very high intensity. Subsequently, they were asked to select the cheese that was most pleasing. For each Paipa cheese sample to be evaluated, slices of $10 \mathrm{~g} \mathrm{(6,0} \mathrm{cm} \mathrm{long,} \mathrm{4,0} \mathrm{cm} \mathrm{wide} \mathrm{and} \mathrm{1,5} \mathrm{cm} \mathrm{thick)} \mathrm{were} \mathrm{given} \mathrm{to} \mathrm{the} \mathrm{participants.} \mathrm{The} \mathrm{slices}$ were presented simultaneously to eliminate impacts caused by the order of presentation and were arbitrarily labeled. After the sensory analysis of each cheese sample, panelists rinsed their mouths with purified water and neutralized the taste with saltine crackers to remove any aftertaste. The sensory analysis took into account the standard ISO 13299 (2016).

\section{Statistical Analysis}

The statistical analysis of the data was carried out using the statistical program "R". A block design with only one factor: type of chymosin ; two treatments: recombinant chymosin (RC) and chymosin of microbial origin (CMO), and three blocks: milk batch was used. Analysis of variance ANOVA was performed using a significance level of 0,05 , following the statistical model described by equation 3 .

$$
\begin{aligned}
& Y_{i j}=\mu+\beta_{j}+\tau_{i}+\sum_{i j}, \\
& i=1,2, \ldots, k j=1,2, \ldots, b
\end{aligned}
$$

Where: $Y_{i j}=$ response of treatment $i$ in block $j, \mu=$ general mean, $\beta_{j}=$ effect of the $j^{\text {th }}$ block, $\tau_{i}=$ effect of the $i^{\text {th }}$ treatment, $\mathbb{E}_{i j}=$ experimental error in unit j for treatment $\mathrm{i}$.

\section{RESULTS}

\section{Preliminary analysis on fresh raw milk}

Physicochemical composition and content of lactic acid bacteria. Table 1 presents the physicochemical composition of the milk used to make the analyzed cheeses.

Table 1. Physicochemical composition of milk.

\begin{tabular}{|l|c|c|}
\hline \multicolumn{1}{|c|}{ Característic } & Result & Accepted value* $^{*}$ \\
\hline $\mathrm{pH}$ & $6,58 \pm 0,10$ & 6,5 \\
\hline Percentage of proteins & $3,10 \pm 0,12$ & 3,0 \\
\hline Percentage of total solids & $11,68 \pm 0,18$ & $>11,4$ \\
\hline Percentage of fats & $3,19 \pm 0,29$ & 3,0 \\
\hline Percentage of acidity & $0,16 \pm 0,004$ & 0,16 \\
\hline
\end{tabular}

*Value accepted by resolution 70802 of the Superintendencia de Industria y Comercio de Colombia by Paipa cheese (SIC, 2011) 
The results obtained show that the physicochemical composition of the collected milk is adequate for making Paipa cheese. The results fall within the accepted values of $\mathrm{pH}$, protein percentages, total solids, fat, and acidity, established by the regulations that govern its production. The average initial content of LAB was $1,33 \times 10^{7}$ $\mathrm{CFU} / \mathrm{mL}$ of milk which are similar to results obtained in the microbiological analysis carried out on raw milk in the production of Castelmagno cheeses, with values of 6,00 $\times 10^{6} \mathrm{CFU} / \mathrm{mL}$ (Dolci et al., 2010). The high quantity of bacteria is common in raw milk, since both milk and its derivatives are typical means of proliferation.

Coagulant and lipolytic activities of milk-clotting enzymes. Table 2 shows the results of coagulation capacity (coagulant activity) and lipase activity (lipolytic activity) for each type of enzyme.

Table 2. Coagulant and lipolytic activity of the chymosins evaluated.

\begin{tabular}{l|l|l|}
\hline \multicolumn{1}{|c|}{ Activity } & \multicolumn{1}{c|}{ RC } & \multicolumn{1}{c|}{ CMO } \\
\hline Coagulant activity (UCA $/ \mathrm{mL})$ & $1,34 \pm 0,21^{\mathrm{a}}$ & $1,28 \pm 0,19^{\mathrm{a}}$ \\
\hline Lipolytic activity (LU/g) & $22356 \pm 3590^{\mathrm{a}}$ & $28177 \pm 3176^{\mathrm{b}}$ \\
\hline
\end{tabular}
a,b Different letters indicate statistically significant differences
$(P<0,05)$, ANOVA analysis of variance.

There are no significant differences in coagulant activity on milk proteins by the two types of protein precipitants. When comparing the coagulant activity reported by Amira et al. (2018), using chymosin during the preparation of the curd $(\approx 1,11 \mathrm{UCA} / \mathrm{mL})$, it was found that chymosins analyzed presented higher values: RC $(1,34$ $\mathrm{UCA} / \mathrm{mL})$ and $\mathrm{CMO}(1,28 \mathrm{UCA} / \mathrm{mL})$. It should be mentioned that a higher precipitation activity is related to a better specificity towards k-casein and results in a greater hydrolysis rate (Amira et al., 2018).

The evaluation of lipolytic activity showed significant differences. Lipolysis was found to be higher in chymosin microbial origin, which favor the hydrolysis of triglycerides and would generate a greater release of FFA. Since FFAs act as precursors for volatile compounds, this has important implications for the organoleptic properties of the product, mainly in the generation of characteristic odors and flavors (Bertuzzi et al., 2018).

\section{Preparation and analysis of Paipa cheeses}

Physicochemical composition and content of lactic acid bacteria. Table 3 presents the physicochemical composition of the produced Paipa cheeses.

Table 3. Physicochemical composition.

\begin{tabular}{|l|c|c|}
\hline \multicolumn{1}{|c|}{ Characterístic } & RC & CMO \\
\hline $\mathrm{pH}$ & $5,67 \pm 0,32^{\mathrm{a}}$ & $5,56 \pm 0,32^{\mathrm{b}}$ \\
\hline Percentage of salt & $2,12 \pm 0,04^{\mathrm{a}}$ & $2,28 \pm 0,06^{\mathrm{a}}$ \\
\hline Percentage of protein & $28,05 \pm 0,13^{\mathrm{a}}$ & $31,65 \pm 0,16^{\mathrm{a}}$ \\
\hline Percentage of protein in dry base & $43,69 \pm 0,23^{\mathrm{a}}$ & $47,31 \pm 0,12^{\mathrm{a}}$ \\
\hline Percentage of total solids & $65,17 \pm 0,87^{\mathrm{a}}$ & $66,05 \pm 2,56^{\mathrm{a}}$ \\
\hline Percentage of humidity & $34,83 \pm 0,87^{\mathrm{a}}$ & $33,95 \pm 2,56^{\mathrm{a}}$ \\
\hline Percentage of humidity in defatted cheese & $44,47 \pm 0,06^{\mathrm{a}}$ & $40,23 \pm 0,07^{\mathrm{a}}$ \\
\hline Percentage of fat & $19,49 \pm 0,53^{\mathrm{a}}$ & $17,73 \pm 0,17^{\mathrm{a}}$ \\
\hline Percentage of fat in dry material & $30,36 \pm 0,46^{\mathrm{a}}$ & $26,50 \pm 0,37^{\mathrm{a}}$ \\
\hline Activity of water & $0,92 \pm 0,04^{\mathrm{a}}$ & $0,92 \pm 0,07^{\mathrm{a}}$ \\
\hline Percentage of acidity & $1,05 \pm 0,10^{\mathrm{a}}$ & $1,16 \pm 0,02^{\mathrm{a}}$ \\
\hline Percentage of yield & $97,12 \pm 3,78^{\mathrm{a}}$ & $93,18 \pm 5,84^{\mathrm{a}}$ \\
\hline
\end{tabular}

a,b Different letters indicate statistically significant differences $(P<0,05)$, ANOVA analysis of variance. 
The physicochemical composition of the produced cheeses showed a significant difference in the $\mathrm{pH}$ of the final product when different types of chymosins are used. In cheeses made with $\mathrm{CMO}$, the pH was lower, which could be related to a greater accumulation of fermentation products such as lactic acid and other organic acids. Although there were differences, they were not significant when using a particular type of chymosin for percentages of salt, protein, protein on a dry base, total solids, humidity, moisture of defatted cheese, fat, fat in dry material, and acidity. When evaluating the percentage of salt, the use of CMO caused a slight increase in its concentration which enhances flavor, but also intervenes in specific characteristics of the product. Changes to the structure, texture, functional properties, extension of the product's shelf life were noted in addition to contributing to the selection of microorganisms through a partial regulation of water in the paste (SIC, 2011; Loudiyi et al., 2018). There were no differences regarding the water activity of the cheeses, finding an activity of 0,92 which is outside the range at which pathogenic bacteria and other microorganisms associated with spoilage grow optimally $(0,94-0,99)$ (Trmčić et al., 2016).

The cheeses made with RC had a higher yield of $97,12 \%$ when compared to those made with CMO: 93,18\%. This behavior was favored by two important factors regarding the optimization of cheese yield. The first factor was the moisture/protein ratio which was higher in RC cheeses $(1,24)$ than CMO cheeses $(1,07)$. The second factor was the fat/protein ratio, which was higher in $\mathrm{RC}$ cheeses $(0,69)$ than $\mathrm{CMO}$ cheeses $(0,56)$ resulting in a more efficient retention of fat and causing the precipitation and agglomeration of proteins resulting in less fat loss from the serum (Pazzola et al., 2019). Despite the fact that the cheeses made with CMO generated a lower yield, it is important to note that in this product, the highest amount of total solids is provided by the quantity of protein.

There were no significant differences in the cheeses analyzed regarding LAB. In RC cheeses there was an average of $5,47 \times 10^{9} \mathrm{CFU} / \mathrm{g}$ while $\mathrm{CMO}$ cheeses had an average of $7,81 \times 10^{9} \mathrm{CFU} / \mathrm{g}$. These results are similar to the analysis of bacterial diversity in Paipa cheese carried out by Castellanos-Rozo et al. (2020) which concludes them to be the main group of microorganisms in this product. Similar LAB contents have been reported in traditional cheeses such as Serra da Canastra and Fruhe with values on the order of $10^{8}-10^{9} \mathrm{CFU} / \mathrm{g}$. These bacteria are derived mainly from the native microbial flora of raw milk and remain in the product until the end of maturation due to their acid-tolerance (Kamimura et al., 2020; Murgia et al., 2020). Important populations of these bacteria in Paipa cheese could favor the development of the functional properties in the product since they have the ability to play a probiotic role and synthesize compounds with antimicrobial capacity such as organic acids (mainly lactic acid), hydrogen peroxide, and bacteriocins that inhibit the degradation and growth of pathogenic bacteria while providing flavor to the cheese (Castro et al., 2016).

The LAB content depending on the type of precipitant and its relation to total FFA will be analyzed in greater detail in Sec. Total free fatty acid quantification.

\section{Lipid composition}

Lipid profile. Figure 1 shows the lipid profile of the Paipa cheeses made with the chymosin RC and CMO. The results are expressed according to: (a) carbon chain length: short chain fatty acids (FA-SC), medium chain fatty acids (FA-MC), and long chain fatty acids (FA-LC); and (b) degree of unsaturation: saturated, monounsaturated, polyunsaturated, and total fatty acids.

The type of chymosin used in the production of Paipa cheese had no significant effect on the concentration of fatty acids. When analyzing Figure $1 \mathrm{a}$, the results indicate that Paipa cheese is mainly made up of FA-LC, secondIy by FA-MC, and to a lesser extent by FA-SC. In general, FA-LC tend to have a lesser influence on flavor when compared to FA-SC and FA-MC. This is due to their high threshold of sensory perception related to background flavors which are not directly perceived at first taste. In contrast, the perception threshold for non-esterified FA-SC and FA-MC is lower, such that even at low concentrations they have significant impacts on the development of aromas and flavors (Güler, 2005). 


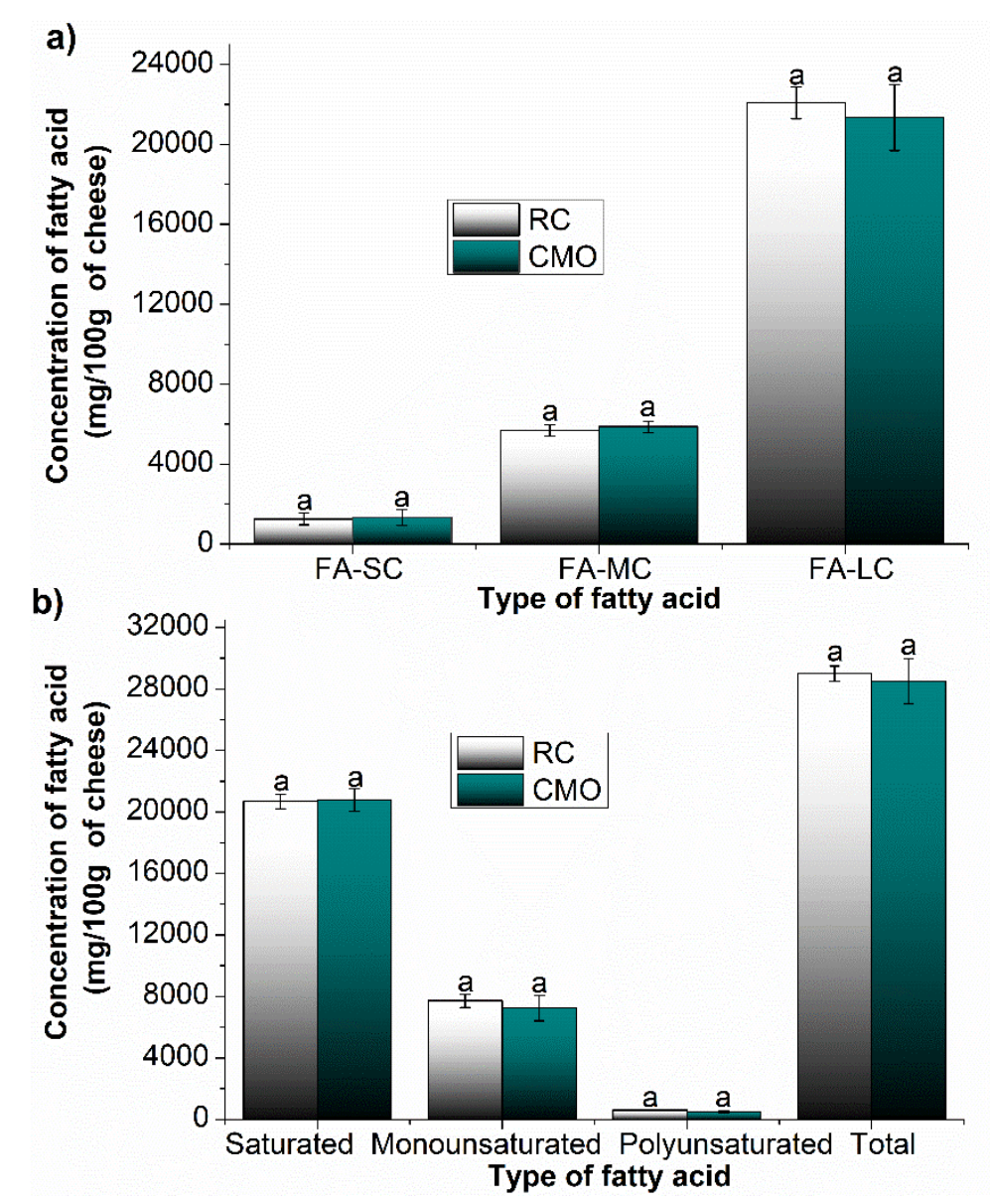

Figure 1. Lipid composition. a) Classification by carbon chain length. b) Classification by degree of unsaturation.

${ }^{a, b}$ Different letters indicate statistically significant differences

$(P<0,05)$, ANOVA analysis of variance.

The lipid profile shown in Figure $1 \mathrm{~b}$, shows that Paipa cheese is mainly composed of saturated fatty acids, followed by monounsaturated fatty acids, and to a lesser extent polyunsaturated fatty acids. Saturated fatty acids make up $71,31 \%$ of the total content, where palmitic, myristic, and stearic acids were predominant. When comparing the lipid profiles of the Paipa cheeses made for this paper with Paipa cheeses from three different commercial brands, 7,84 \% more saturated fatty acids were found in their content (data not shown). Unsaturated fatty acids (mono and polyunsaturated) are related to factors such as the origin of raw milk, altitude of the area in which it is produced (Paipa is at 2525 m.a.s.l), and a diet of cattle based on green forage. These factors favor the concentration of this type of fatty acid in milk, compared to those obtained in milk from lower altitudes and from cattle fed with concentrated (Zeppa et al., 2003; Hanus et al., 2018). Monounsaturated fatty acids are beneficial because they are useful as an energy source, reduce blood concentrations of low-density lipoproteins and prevent cardiovascular disease (De Souza et al., 2015). Polyunsaturated fatty acids play an essential role in human health and in the proper function of the brain, heart, and vision (Sokoła-Wysoczańska et al., 2018). It is important to note that no trans fatty acids were found in Paipa cheese, which is positive considering that its intake is related to the development of coronary heart disease, inflammation, endothelial dysfunction, and other diseases associated with increased levels of cholesterol carried by low-density lipoproteins (LDL) (Oteng and Kersten, 2020). The characteristics found in Paipa cheese can be further studied to determine each of the stages and factors that intervene in the production process and in order to improve the lipid, protein, and microbiolo- 
gical composition of the raw material and therefore of the finished product. Table 4 presents the contents of the fatty acids of greater nutritional and organoleptic relevance in the cheeses analyzed.

Table 4. Fatty acids of greater nutritional and organoleptic relevance in cheeses.

\begin{tabular}{|l|l|l|l|}
\hline \multicolumn{1}{|c|}{ Fatty acid } & \multicolumn{1}{|c|}{$\begin{array}{c}\text { Retention time } \\
\text { (min) }\end{array}$} & \multicolumn{1}{c|}{$\begin{array}{c}\text { RC } \\
\text { (mg/100 g of cheese) }\end{array}$} & \multicolumn{1}{c|}{$\begin{array}{c}\text { CMO } \\
\text { (mg/100 g of cheese) }\end{array}$} \\
\hline Butyric (C4:0) & 3,787 & $656,33 \pm 168,05^{\mathrm{a}}$ & $672,00 \pm 238,27^{\mathrm{a}}$ \\
\hline Caproic (C6:0) & 4,153 & $587,33 \pm 126,47^{\mathrm{a}}$ & $652,33 \pm 165,30^{\mathrm{a}}$ \\
\hline Caprylic (C8:0) & 4,974 & $350,33 \pm 59,50^{\mathrm{a}}$ & $387,00 \pm 67,64^{\mathrm{a}}$ \\
\hline Capric (C10:0) & 6,565 & $728,33 \pm 102,38^{\mathrm{a}}$ & $779,00 \pm 113,65^{\mathrm{a}}$ \\
\hline Lauric (C12:0) & 8,906 & $858,00 \pm 69,16^{\mathrm{a}}$ & $894,33 \pm 82,25^{\mathrm{a}}$ \\
\hline a-Linolenic (C18:3n3) & 24,413 & $152,00 \pm 20,07^{\mathrm{a}}$ & $126,33 \pm 22,01^{\mathrm{a}}$ \\
\hline Eicosapentaenoic (C20:5n3) & 32,925 & $19,00 \pm 5,00^{\mathrm{a}}$ & $14,00 \pm 4,00^{\mathrm{a}}$ \\
\hline Linoleic (C18:2n6c) & 22,562 & $390,67 \pm 23,71^{\mathrm{a}}$ & $332,33 \pm 39,55^{\mathrm{a}}$ \\
\hline Arachidonic (C20:4n6) & 30,480 & $18,33 \pm 4,04^{\mathrm{a}}$ & $13,67 \pm 3,06^{\mathrm{a}}$ \\
\hline Oleic (C18:1n9c) & 21,202 & $7046,00 \pm 374,72^{\mathrm{a}}$ & $6571,67 \pm 771,83^{\mathrm{a}}$ \\
\hline Eicosenoic (C20:1n9) & 27,217 & $12,33 \pm 0,58^{\mathrm{a}}$ & $12,67 \pm 1,53^{\mathrm{a}}$ \\
\hline
\end{tabular}

a,b Different letters indicate statistically significant differences $(P<0,05)$, ANOVA analysis of variance.

There were no significant differences in the content of fatty acids of nutritional and organoleptic relevance in cheeses made with RC or CMO. Regardless of the type of chymosin (E.C. 3.4.23.4), the lipid profiles show the presence of the fatty acids responsible for generating the characteristic flavors and aromas in matured cheeses. Among the fatty acids that provide the acidic flavor of cheese are capric acid, which is a flavor enhancer and is associated with a burning acidic flavor, and caproic acid, which has a pungent flavor (Güler, 2005). The rancid and bitter flavors are mainly due to the presence of capric and butyric acids, of which the latter also contributes to the typical cheese flavor. In addition to these flavors which are characteristic of Paipa cheese, there are others which are characteristic of the lipolytic activity of bacterial enzymes including LAB, on matured cheeses. This is how the soapy and spicy flavors are related to the presence of lauric, and caprylic acids (Güler, 2005).

The contents of butyric, caprylic, and caproic acids were higher than those found in the lipid profiles of commercial Paipa cheeses ( $\approx 150 \mathrm{mg} / 100 \mathrm{~g}$ of cheese) evaluated by our research group (data not shown). These differences can be attributed to climatic factors according to the seasonal stage of milk collection for the production of cheeses and differences in the livestock selection and storage procedures, among other aspects that would impact the lipid composition of both the raw material and the final product; however, its effect on the organoleptic properties depends mainly on the specific hydrolytic activity of each fatty acid as well as on the dynamics of its release.

A chromatographic analysis on the fatty acids of nutritional importance indicated an important content of omegas 3, 6, and 9 such as: linolenic, eicosapentaenoic, linoleic, arachidonic, oleic and eicosenoic acids. Omega-3s such as linolenic and eicosapentaenoic acid, have shown effect to reducing the possibility to suffer cardiovascular related problems (Fleming and Kris-Etherton, 2014). In addition to omega-3s, omegas-6s, and those derived from long-chain polyunsaturated fatty acids such as arachidonic and linoleic acid, have a central role in the structure and functions of the cell membrane that promote neonatal growth, metabolism of neurotransmitters, the development of the visual and nervous systems, and provide beneficial anti-inflammatory and immunological effects (Santillo et al., 2018). In the case of omega-9s, oleic acid was one of the fatty acids found in the highest proportion making up $23,5 \%$ of the total fatty acids present. This compound reduces the incidences of developing cardiovascular disease. These qualities present in Paipa cheese highlight its nutritional quality and should be used to search for alternatives that strengthening and broaden its use. 
Total FFA quantification. The impact of the type of milk-clotting enzymes on lipolysis, understood as the degree of FFA release, by hydrolytic action of lipolytic enzymes is presented in Table 5.

Table 5. Effect of milk-clotting enzymes on lipolysis and increase of lactic acid bacteria.

\begin{tabular}{|l|c|c|}
\hline & RC & CMO \\
\hline Lipolysis (mg of FFA/100 g of cheese) & $7,52 \pm 2,89^{\mathrm{a}}$ & $162,07 \pm 9,43^{\mathrm{b}}$ \\
\hline Lactic acid bacteria (CFU/g) & $5,47 \times 10^{9 \mathrm{a}}$ & $7,81 \times 10^{9} \mathrm{a}$ \\
\hline
\end{tabular}

a,b Different letters indicate statistically significant differences $(P<0,05)$, ANOVA analysis of variance.

The results obtained indicated significant differences in lipolysis in the cheeses made with RC and CMO. The CMO cheeses presented a higher degree of lipolysis, releasing $162,07 \pm 9,43 \mathrm{mg}$ of FFA/100 $\mathrm{g}$ of cheese which corresponds to $0,57 \%$ of the total fatty acids. The RC cheeses resulted in a lower lipolysis, resulting in a release of $7,52 \pm 2,89 \mathrm{mg}$ of FFA $100 \mathrm{~g}$ of cheese or $0,03 \%$ of all fatty acids. A higher content of released FFA is related to a higher intensity in the perceived flavors. This was the case in the sensory analysis carried out on Azul, Limburguer, and Roquefort cheeses which were classified as stale, strong cheeses with butyric flavors, which presented high concentrations of FFA (on average 2395 mg FFA/100 g of cheese). In contrast, cheeses such as Port Salut, Monterey, Edam, and Colby, had mild milk flavors and are characterized by low levels of FFA (on average $58 \mathrm{mg} F F A / 100 \mathrm{~g}$ cheese) (Reps et al., 2006; Thierry et al., 2017). The impact of lipolysis on the intensity of the flavors of Paipa cheeses will be observed in detail in Sec. Sensory analysis. In matured products made with raw milk, the production of FFA is normal since it is responsible for the typical flavors of these cheeses. Additionally, they act as precursors of the volatile compounds such as alcohols, aldehydes, ketones, and esters among other compounds responsible for the flavor and aroma of the cheese. It can also negatively impact the taste of cheeses by introducing defects such as rancid flavors accompanied by the production of "Spicy" flavors which are often unpleasant to the palate of consumers. There was no excessive lipolysis for any of the Paipa cheeses analyzed, which would account for a development of flavors and aromas typical of matured products. Although a higher intensity of sour and bitter flavors was found in CMO cheese, it did not reach the point of being "unpleasant" for consumption.

The LAB in matured cheeses are a source of lipolytic enzymes and their presence favors the release of FFA (Lopez et al., 2006). Despite having generated greater lipolysis in CMO cheese, no significant differences were found in terms of $\mathrm{LAB}$ content between $\mathrm{RC}$ and $\mathrm{CMO}$ cheeses in the current study. It can therefore be inferred that this was not a factor directly related to the higher lipolysis generated in $\mathrm{CMO}$ cheese. It is important to note that there are several sources of lipolytic enzymes which include LAB, the lipoprotein lipase in milk, and the type of milk-clotting enzyme, among others. The results from the current study indicate that the enzymes from the CMO significantly influenced the production of FFA which indicated both a higher lipolytic activity and FFA content.

Sensory analysis. When comparing Paipa cheeses made with RC and $\mathrm{CMO}$, there were no significant differences in the characteristics such as color, size, brightness, porosity, and greasy appearance. Differences between cheeses made using the two methods included yield which was $97,12 \%$ for RC cheese and $93,18 \%$ for CMO cheese and the color of the paste which was creamy yellow in cheeses made with RC and creamy white for those made with CMO. Figure 2 contains a radar chart related to the flavor, texture, and olfactory properties of the cheeses. 
a)

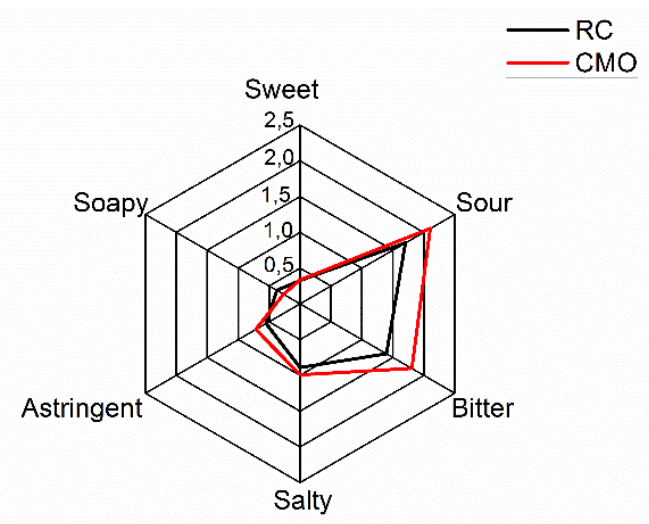

c)

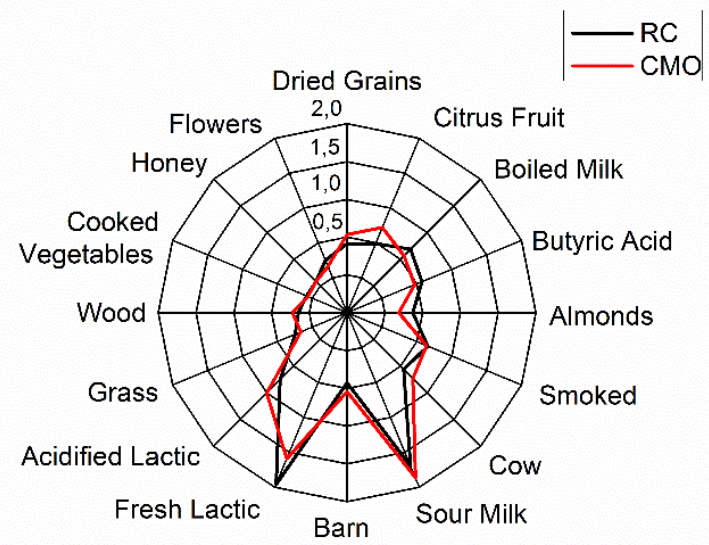

b)

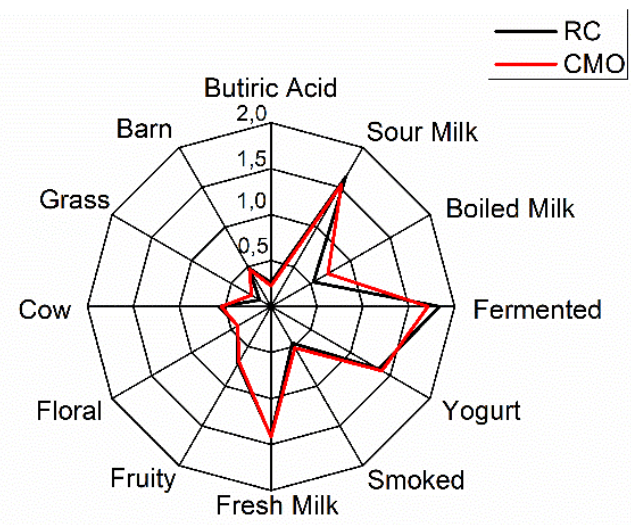

d)

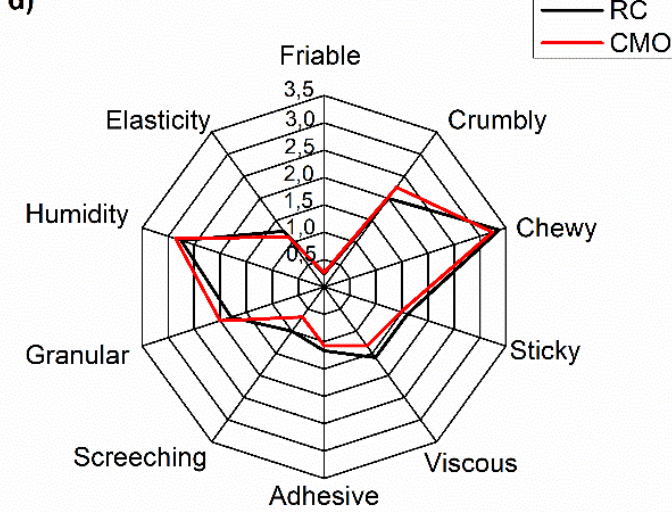

Figure 2. Sensory analysis. a) taste. b) orthonasal olfactory sensation. c) retronasal olfactory sensation. d) tactile sensation.

The graphs show the average of the score given to each attribute in a range of 0-5, with 0: low and 5: high.

The sensory analysis of the RC and CMO cheeses showed large differences regarding the flavor and the olfactory and tactile properties of the cheeses. In Figure 2a, the CMO cheeses had an intense sour and bitter flavor as well as a slightly higher astringent sensation compared to the RC cheese. Astringency, soapy, spicy, or burning acid flavors are characteristic of matured cheeses and are related to the presence of lauric, caprylic and caproic acid (Güler, 2005). These acids are found in a higher concentration in CMO cheeses as shown in the lipid analysis (Table 4).

The main differences in orthonasal olfactory sensations are found in the aromas of sour and fermented milk, which were more intense in RC cheeses. The odors of grass and boiled milk were more predominant for $\mathrm{CMO}$ cheeses as shown in Figure 2b. These aromas occurred as a result of the butyric and capric acid in both cheeses (Güler, 2005). Depending on the concentration of the acids in the cheese, a rancid or typical cheese flavor would be exhibited.

Regarding the retronasal olfactory sensations as seen in Figure $2 c$, the $\mathrm{RC}$ cheeses presented a greater intensity in the aromas of boiled milk and fresh lactic. The $\mathrm{CMO}$ cheeses presented a primarily acidified lactic, cow, and fruity citrus smells. These results support the finding of higher concentrations of caproic and capric acid in CMO cheeses (Table 4) which are related to goat cheese and stable aromas (Güler, 2005). In low concentrations of FFA in RC cheese typically generate smooth aromas of fresh milk.

Regarding the tactile sensation (manual and mouth texture) (Figure 2d), the CMO cheeses were more granular and crumblier. RC cheeses were more elastic, sticky, viscous, and screeching. These characteristics are due to the physicochemical composition of the processed cheeses (Table 3). Since CMO cheeses have a lower percentage of fat they are less viscoelastic, have a higher humidity, as well as a less cohesive texture (Shi et al., 2020). 
A sensory analysis of the cheeses showed that despite a low threshold of perception of the FA-SC: 200-900 $\mu \mathrm{mol} / \mathrm{kg}$; small changes in the concentration of these compounds can cause significant changes in the perception of the product. The most notable differences in the attributes analyzed were found in the sour and bitter flavors. Additionally, smells of cow, sour milk, and stable milk were the main reasons why CMO cheese presented a lower degree of acceptance by the panelists (33,33\% acceptance).

\section{CONCLUSIONS}

The kind of chymosin (E.C. 3.4.23.4) used in the production of Paipa cheeses (a colombian semi-matured dairy product), significantly influences the lipolysis, release of FFA and organoleptic properties of the product. The CMO produced a greater lipolytic activity and favored a greater release of FFA when compared to the lipolytic activity and release of FFA in RC cheeses. As a result of the higher lipolysis, the cheeses made with CMO tended to be perceived as having more acidic, rancid, bitter, and soapy flavored. This was attributed to FA-SC and the butyric, caproic, caprylic, capric, and lauric acids which were perceived to be less preferable in the sensory analysis. The type of protein precipitant did not significantly influence LAB proliferation; however, the counts of these bacteria indicated that they are of the important sources of lipolytic enzymes in the product. This contributes to the development of flavors, aromas, the promotion of antimicrobial activity, and a probiotic role in cheeses. The lipid composition of the product was not impacted by the use of a particular milk-clotting enzyme. This was seen as a result of a high content of saturated fatty acids, important omega 3, 6, and 9 such as linolenic, linoleic, and oleic acids, and the absence of trans fats. The current study highlights the importance of the impact of chymosin on the organoleptic and nutritional properties of matured cheeses in general as well as Paipa cheese; while providing the possible impact it may have on its commercial activity. Studies concerning the process of release of free fatty acids during maturation and its relationship with organoleptic properties are recommended.

\section{ACKNOWLEDGEMENT}

This work was assisted by the Universidad Pedagógica y Tecnológica de Colombia (SGI 2396 and SGI 2140 grant). Thanks the Paipa cheese factory "Lácteos Factory" for their advice and technology support.

\section{REFERENCES}

AMIRA, AMAL; BLECKER, CHRISTOPHE; RICHEL, AURORE; ARGÜELLES-ARIAS, ANTHONY; FICKERS, PATRICK; FRANCIS, FRÉDÉRIC; BESBES, SOUHAIL; ATTIA, HAMADI. Influence of the ripening stage and the lyophilization of wild cardoon flowers on their chemical composition, enzymatic activities of extracts and technological properties of cheese curds. Food Chemistry, v. 245, 2018, p. 919-925. https://doi.org/10.1016/j.foodchem.2017.11.082

ASSOCIATION OF OFFICIAL ANALYTICAL CHEMISTS (AOAC). Official Methods of Analysis. Maryland (USA): 1990, $700 \mathrm{p}$.

BERTUZZI, ANDREA S.; McSWEENEY, PAUL L.H.; REA, MARY C.; KILCAWLEY, KIERAN N. Detection of Volatile Compounds of Cheese and Their Contribution to the Flavor Profile of Surface-Ripened Cheese. Comprehensive Reviews in Food Science and Food Safety, v. 17, n. 2, 2018, p. 371-390.

https://doi.org/10.1111/1541-4337.12332 
BEVILACQUA, ANTONIO; SPERANZA, BARBARA; SANTILLO, ANTONELLA; ALBENZIO, MARZIA; GALLO, MARIANGELA; SINIGAGLIA, MILENA; CORBO, MARIA ROSARIA. Alginate-microencapsulation of Lactobacillus casei and Bifidobacterium bifidum: Performances of encapsulated microorganisms and bead-validation in lamb rennet. LWT-Food Science and Technology, v. 113, 2019, p. 1-6. https://doi.org/10.1016/j.Iwt.2019.108349

CÂMARA, SANDRA P.A.; DAPKEVICIUS, AIRIDAS; ROSA, HENRIQUE J.D.; SILVA, CÉLIA C.G.; MALCATA, XAVIER; ENES-DAPKEVICIUS, MARIA L.N. Physicochemical, biochemical, microbiological and safety aspects of Pico cheese: Assessment throughout maturation and on the final product. International Journal of Dairy Technology, v. 70, n. 4, 2017, p. 542-555. https://doi.org/10.1111/1471-0307.12424

CASTELLANOS-ROZO, JOSÉ; PÉREZ-PULIDO, RUBÉN; GRANDE, MARÍA-JOSÉ; LUCAS, ROSARIO; GÁLVEZ, ANTONIO. Analysis of the bacterial diversity of Paipa cheese (a traditional raw cow's milk cheese from Colombia) by high-throughput sequencing. Microorganisms, v. 8, n. 218, 2020, p. 2-12. https://doi.org/10.3390/microorganisms8020218

CASTRO, R.D; DE OLIVEIRA, LETICIA G.; SANT'ANNA, FELIPE M.; PINHEIRO-LUIZ, LIVIA- MARÍA; SANDES, SAVIO; SILVA, C.I.F.; SILVA, A.M; NUNES, ALVARO C.; PENNA, CLAUDIA; SOUZA, M.R. Lactic acid microbiota identification in water, raw milk, endogenous starter culture, and fresh Minas artisanal cheese from the Campo das Vertentes region of Brazil during the dry and rainy seasons. Journal of Dairy Science, v. 99 , n. 8, 2016, p. 6086-6096. https://doi.org/10.3168/jds.2015-10579

COLOMBIA. SUPERINTENDENCIA DE INDUSTRIA Y COMERCIO (SIC). Resolución Nº 70802. Bogotá (Colombia): 2011, $12 \mathrm{p}$.

DE SOUZA, RUSSELL J.; MENTE, ANDREW; MAROLEANU, ADRIANA; COZMA, ADRIAN I.; HA, VANESSA; KISHIBE, TERUKO; ULERYK, ELIZABETH; BUDYLOWSKI, PATRICK;SCHÜNEMANN, HOLGER; BEYENE, JOSEPH; ANAND, SONIA S. Intake of saturated and trans unsaturated fatty acids and risk of all cause mortality, cardiovascular disease, and type 2 diabetes: Systematic review and meta-analysis of observational studies. The BMJ, v. 351, 2015, p. 1-16. https://doi.org/10.1136/bmj.h3978

DOLCI, PAOLA; ALESSANDRIA, VALENTINA; RANTSIOU, KALLIOPI; BERTOLINO, MARTA; COCOLIN, LUCA; Microbial diversity, dynamics and activity throughout manufacturing and ripening of Castelmagno PDO cheese. International Journal of Food Microbiology, v. 143, n. 1-2, 2010, p. 71-75. https://doi.org/10.1016/j.ijfoodmicro.2010.07.007

FLEMING, JENNIFER A.; KRIS-ETHERTON, PENNY M. The evidence for $\boldsymbol{\alpha}$-Linolenic acid and cardiovascular disease benefits: Comparisons with eicosapentaenoic acid and docosahexaenoic acid. Advances in Nutrition, v. 5, n. 6, 2014, p. 863S-876S. https://doi.org/10.3945/an.114.005850

GÜLER, ZEHRA. Quantification of free fatty acids and flavor characteristics of Kasar Cheeses. Journal of Food Lipids, v. 12, 2005, p. 209-221. https://doi.org/10.1111/j.1745-4522.2005.00018.x

HANUŠ, OTO; SAMKOVÁ, EVA; KŘÍŽOVÁ, LUDMILA; HASOŇOVÁ, LUCIE; KALA, ROBERT. Role of fatty acids in milk fat and the influence of selected factors on their variability-a review. Molecules, v. 23, n. 7, 2018 , p. 1-32. https://doi.org/10.3390/molecules23071636

SUIZA. ORGANIZACIÓN INTERNACIONAL DE NORMALIZACIÓN (ISO). ISO 13299: Análisis sensorial. Metodología. Guía general para establecer un perfil sensorial: Ginebra (Suiza): 2016, 48 p.

KAMIMURA, BRUNA A.; CABRAL, LUCÉLIA; NORONHA, MELLINE F.; BAPTISTA, RAFAELA C.; NASCIMENTO, HENRY M.; SANT'ANA, ANDERSON S. Amplicon sequencing reveals the bacterial diversity in milk, dairy premises and Serra da Canastra artisanal cheeses produced by three different farms. Food Microbiology, v. 89, 2020, p. 1-12. https://doi.org/10.1016/j.fm.2020.103453 
LOPEZ, CHRISTELLE; MAILLARD, MARIE-BERNADETTE; BRIARD-BION, VALERIE; CAMIER, BENEDICTE; HANNON, JOHN A. Lipolysis during ripening of Emmental cheese considering organization of fat and preferential localization of bacteria. Journal of Agricultural and Food Chemistry, v. 54, n. 16, 2006, p. 5855-5867. https://doi.org/10.1021/jf060214l

LOUDIYI, MOHAMMED; RUTLEDGE, DOUGLAS-NEIL; AÏT-KADDOUR, ABDERRAHMANE. ComDim for explorative multi-block data analysis of Cantal-type cheeses: Effects of salts, gentle heating and ripening. Food Chemistry, v. 264, 2018, p. 401-410. https://doi.org/10.1016/j.foodchem.2018.05.039

MURGIA, MARCO A.; DEIANA, PIETRINO; NUDDA, ANNA; CORREDDU, FABIO; MONTANARI, LUIGI; MANGIA, NICOLETTA P. Assessment of microbiological quality and physicochemical parameters of fruhe made by Ovine and Goat Milk: A sardinian (Italy) cheese. Fermentation, v. 6, n. 4, 2020, p. 2-10. https://doi.org/10.3390/fermentation6040119

NIÑO- DE ONSHUUS, YOLANDA. Manual de elaboración de queso Paipa. Bogotá (Colombia): Instituto de Ciencia y Tecnología de Alimentos (ICTA), Universidad Nacional de Colombia, 1998, 45 p.

OTENG, ANTWI-BOASIAKO; KERSTEN, SANDER. Mechanisms of Action of trans Fatty Acids. Advances in Nutrition, v. 11, n. 3, 2020, p. 697-708. https://doi.org/10.1093/advances/nmz125

PAZZOLA, MICHELE; STOCCO, GIORGIA; DETTORI, MARIA L.; BITTANTE, GIOVANNI; VACCA, GIUSEPPE M. Effect of goat milk composition on cheesemaking traits and daily cheese production. Journal of Dairy Science, v. 102, n. 5, 2019, p. 3947-3955. https://doi.org/10.3168/jds.2018-15397

REPS, ARNOLD; JEDRYCHOWSKI, LUCJAN; WIŚNIEWSKA, KRYSTYNA; JANKOWSKA, AGNIESZKA. Application of a coagulating preparation obtained with Rhizomucor Miehei N in cheese-making. Pakistan Journal of Nutrition, v. 5, n. 2, 2006, p. 97-101. https://doi.org/10.3923/pjn.2006.97.101

ROMERO DEL CASTILLO-SHELLY, ROSER; MESTRES-LAGARRIGA, JOSEP. Productos lácteos. Tecnología. 1 ed. Barcelona (España): Edicions UPC, 2004, 228 p.

SANTILLO, ANTONELLA; FIGLIOLA, LUCIA; CILIBERTI, MARIA G.; CAROPRESE, MARIANGELA; MARINO, ROSARIA; ALBENZIO, MARZIA. Focusing on fatty acid profile in milk from different species after in vitro digestion. Journal of Dairy Research, v. 85, n. 2, 2018, p. 257-262. https://doi.org/10.1017/S0022029918000274

SHI, YONGQI; QI, LIANG; XUEMEI, SONG; YAN, ZHANG. Effect of Fat Content on Texture, Rheology and Microstructure of Yak Milk Hard Cheese. Shipin Kexue, v. 41, n. 20, 2020, p. 14-19.

10.7506/spkx1002-6630-20190617-181

SOKOŁA-WYSOCZAŃSKA, EWA; WYSOCZAŃSKI, TOMASZ; WAGNER, JOLANTA; CZYŻ, KATARZYNA; BODKOWSKI, ROBERT; LOCHYŃSKI, STANISŁAW; PATKOWSKA-SOKOŁA, ANDBOŻENA. Polyunsaturated fatty acids and their potential therapeutic role in cardiovascular system disorders. Nutrients, v. 10, n. 1, 2018, p. 1-21. https://doi.org/10.3390/nu10101561

THIERRY, ANNE; COLLINS, YVONNE F.; ABEIJÓN MUKDSI, M.C.; MCSWEENEY, PAUL L.H.; WILKINSON, MARTIN G.; SPINNLER, HENRI E. In: Cheese: Chemistry, Physics and Microbiology. Lipolysis and Metabolism of Fatty Acids in cheese. 4 ed. Saint Louis (USA): Academic Press, 2017, p. 423-444.

TRMCIC, ALJOSA; CHAUHAN, KHUSHBOO; KENT, DAVID J.; RALYEA, ROBERT D.; MARTIN, NICOLE H.; BOOR, KATHRYN J.; WIEDMANN, MARTIN. Coliform detection in cheese is associated with specific cheese characteristics, but no association was found with pathogen detection. Journal of Dairy Science, v. 99 , n. 8, 2016, p. 6105-6120.

https://doi.org/10.3168/jds.2016-11112 
ZEPPA, GIUSEPPE; GIORDANO, MANUELA; GERBI, VINCENZO; ARLORIO, MARCO. Fatty acid composition of Piedmont "Ossolano" cheese. Le Lait, v. 83, n. 2, 2003, p. 167-173. doi:10.1051/lait:2003007. https://doi.org/10.1051/lait:2003007 